\title{
The New Normal: Social Media's Novel Roles and Utilisation
}

\author{
Rety Palupi ${ }^{1}$, Mincho Slavov ${ }^{2}$ \\ ${ }^{1}$ Universitas Bina Sarana Informatika, rety.ryp@bsi.ac.id \\ ${ }^{2}$ Universitas Airlangga, mincho.radoslavov.slavov-2018@pasca.unair.ac.id
}

\begin{abstract}
ABSTRAK
Pada dekade terakhir media sosial telah mengalami pertumbuhan dan pengaruh yang signifikan hingga melampaui batas yang tidak pernah terjadi sebelum masa pandemi COVID-19. Penelitian ini bertujuan untuk mengidentifikasi dan memvalidasi peran baru dan cara media sosial digunakan pada era Kenormalan Baru. Selain itu, hubungan antara media sosial dan kenormalan baru akan dijabarkan dalam penjelasan mengenai beberapa publikasi tentang protokol Kesehatan pencegahan COVID-19 dengan menerapkan teori uses and gratification. Penulis juga berpendapat bahwa kenormalan baru menawarkan kemungkinan unik untuk pengembangan dan memperluas fitur media sosial, dalam hal ini pada fungsi dan cara penggunaan. Pada penelitian ini memberikan informasi bahwa baik akademisi maupun komunitas bisnis perlu pengetahuan yang komprehensif dan terbaru tentang meningkatnya pengaruh media sosial pada gaya hidup masyarakat.
\end{abstract}

Kata kunci: media sosial, pemanfaatan, digitalisasi, kenormalan baru, Covid-19

\begin{abstract}
In the last decade social media has seen a significant growth and influence that reached an unprecedent levels during the COVID-19 pandemic. This research aims to identify and validate the new roles and way social media can be utilised in the era of New Normal. In addition, the relationship between social media and the new normal will be explored in the light of the post COVID-19 protocols by applying uses and gratification theory. The authors argue that new normal is offering unique possibilities for development and expanding the social media features, functions and way of use. This research provides both academics and the business community with a comprehensive and up-to-date knowledge about the increasing influence of social media on people's lifestyle.
\end{abstract}

Keywords: social media, utilisation, digitalisation, new normal, Covid-19 


\section{INTRODUCTION}

The Internet and digital technologies have been at the heart of human life for decades. Through globalization in a changing and transforming world, significant developments are taking place in the economic, social, technological, and cultural spheres. Participating in social media today, sharing messages in the virtual environment, sharing visual and audio elements, sending e-mails, making calls, and attending online conferences, playing online games are becoming increasingly popular. The international network, namely the services provided by the Internet, which is expressed as a network between networks, is continuously growing, and the digital world is reaching an irreplaceable dimension and influence (Arda, 2020). In cases where a big part of society is involved, social media is often a leading player (Figure 1).

The new type of coronavirus pandemic (Covid-19), which affects the whole world, has caused a new normal protocol to emerge, to take shape, and profoundly affect society. On December 31st, 2019, 27 cases of pneumonia of unknown etiology were detected in Wuhan City, Hubei Province, China. These patients are mostly clinical dry cough, shortness of breath, fever, and bilateral pulmonary infiltrates. Later, as a result of research conducted by the World Health Organization, this disease was named Covid-19 (Sohrabi et al., 2020). With over three million cases globally, the COVID-19 pandemic caused unseen disruption to our society - people were not able to leave their homes, physical and face-to-face social distancing measures were imposed globally, and this has significantly increased the use of the Internet and digital technology.

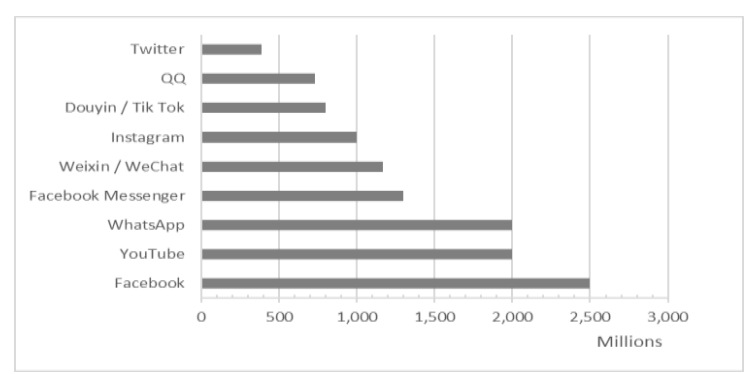

Figure 1.

Most popular social media, ranked by number of users (April 2020)
It was observed that social changes took place immediately after pandemics occurring worldwide. Especially after the Covid-19 pandemic, it is expressed by many scientists that the new normal will emerge, which is already a reality (Laura \& Corwin, 2020; Ting, Carin, Dzau, \& Wong, 2020).

In the Covid-19 pandemic, which coincided with this period, traditional media has been replaced by new media, and social media became dominant. People all over the world, from all generations, flocked the Internet as a primary news source when looking for the latest updates on the Covid-19 global pandemic (Table 1). It is noticeable that even among the generation of "baby boomers," generally considered as quiescent in regards to social media usage, the time spent during the Covid-19 outbreak increased with nearly $37 \%$. For media sellers, content creators, and business, this means audiences are skyrocketing, and for ad buyers have never been easier to reach their desired and highly engaged audience.

Table 1.

Daily time spent on social media during Covid-19 outbreak (March 2020)

Source: Authors, data from https://emarketer.com

\begin{tabular}{lccc}
\hline & $\begin{array}{c}\text { Spending } \\
\text { more time }\end{array}$ & $\begin{array}{c}\text { Spending the } \\
\text { same time }\end{array}$ & $\begin{array}{c}\text { Spending } \\
\text { less time }\end{array}$ \\
\hline $\begin{array}{l}\text { Gen Z } \\
(18-20)\end{array}$ & $66.3 \%$ & $24.2 \%$ & $9.5 \%$ \\
\hline $\begin{array}{l}\text { Millennials } \\
(21-38)\end{array}$ & $69.2 \%$ & $27.9 \%$ & $2.9 \%$ \\
\hline $\begin{array}{l}\text { Gen X } \\
(39-55)\end{array}$ & $53.2 \%$ & $41.6 \%$ & $5.1 \%$ \\
\hline $\begin{array}{l}\text { Baby } \\
\text { boomers } \\
(56-74)\end{array}$ & $36.8 \%$ & $55.9 \%$ & $7.4 \%$ \\
\hline
\end{tabular}

\section{LITERATURE REVIEW}

Social media is a communication construct that allows users to communicate without boundaries. The fundamental principle of uses and gratifications theory, used in this study, is that individuals will seek out media among competitors that fulfill their needs and leads to ultimate gratifications (Hollenbaugh, Ferris, \& Casey, 2020).

Numerous researches performed in the past years have made known that the obtained satisfaction is sound conjecture for recurring 
media use (Innova, 2016; Kaye \& Johnson, 2017).

While widely used in other disciplines, uses and gratifications theory is relatively underestimated when the research is focused on revealing the changing social media uses. Among the uses and gratifications paradigms available in the literature, this research is adopting the following frameworks: first, studies have shown social media platforms can be an important source of information, such as finding deals on products, seeking out news, information, and self-education (Meservy, Fadel, Nelson, \& Matthews, 2019).

Second, social media provides instant access to content that is entertaining, including videos, movies, and games (Lev-On, 2017; Rokito, Choi, Taylor, \& Bazarova, 2019). Third, the use of social media as anti-stress therapy and passing the spare time, readily available during the Covid-19 induced. Finally, social media can be an instrument, that allows users to stay up-to-date on what is happening around the world by checking status updates, new photo/video content and live updates (Baumöl, Hollebeek, \& Jung, 2016). The described frameworks revealed five common themes, as follow:

1) social interaction - using social media to interact with others;

2) information-seeking - using social media to seek out information or self-education;

3) time spent - using social media to fulfill time and mitigate monotony;

4) entertainment and leisure - using social media to provide entertainment and enjoyment in order to relieve the stress, caused by the modern lifestyle;

5) communicatory and convenience utility ease of communication and providing information with convenience and usefulness.

\section{RESEARCH METHODOLOGY}

Due to the limited amount of literature on uses and gratifications theory and its relationship to social media, this research was organized as an exploratory study. This research consisted of in-depth interviews with individuals ranging in age from 18 to 59 years old. The qualitative, in-depth interviews were designed to produce responses regarding the uses and satisfactions of social media. A total of 47 respondents were asked why they use social media, why their business competitors and friends use social media, what they enjoy about social media, how they use social media, and how often. The breakdown for gender was 57 percent females and 43 percent males.

\section{DISCUSSION}

\section{Understanding Social Media.}

The concept of social media has a broad range and understandings. Different scientists and researchers have created different definitions for this concept. Schlagwein and $\mathrm{Hu}$ (2018) are seeing social media as a cluster of internetbased applications, build on the basics and technical foundations of the social web (widely known also as Web 2.0).

Web 2.0 facilitates the construction and exchange of user-generated content and creates an opportunity for participating in social networking efficiently and in real-time. Other researchers propose that social media represent activities, practices, and behavior among groups and communities gathered online to share information, and opinions using chat and speech environment, and web-based applications that make it possible to create content and transfer it quickly in the form of words, pictures, videos, and sounds (Agustiningsih, Anindhita, \& Arisanty, 2017).

Theses definition are very general, and scholars, as well as users disagree about the scope and therefore, the meaning of the term social media. Somewhat, the problem is the rapidly changing content with little to no control over the accuracy (Wang, Li, \& Suomi, 2016). However, despite the differences in the definitions, there are six standard social media features that pop-up from the descriptions mentioned above. The main characteristics of social media are represented in Error! Reference source not found. (below).

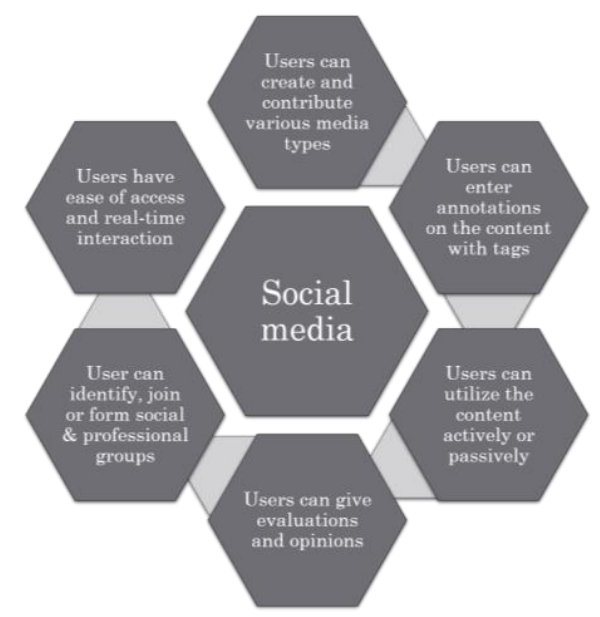

Figure 2.

Social media's main features 


\section{Social Media's structure}

Given the tremendous popularity and growth, social media has been increasingly used by businesses, citizens, and politicians. The role of the digital world in our lives has reached new heights, with more people spending more time doing more things online than ever before - worldwide, as of January 2020, there are 3,80 billion active social media users, or increase of nine percent, compared to January 2019 (Figure 3).

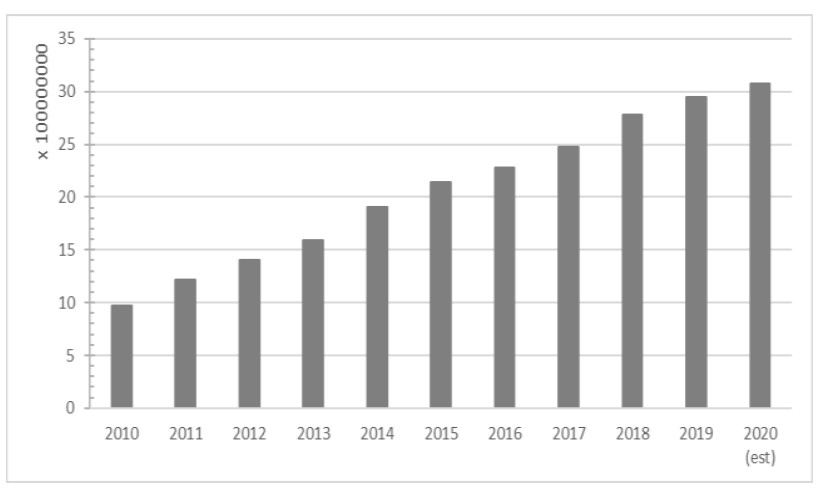

Figure 3.

The global number of social media users 20102020

Social media also plays an active role in determining social opinions and is considered as a viable method for social interaction. It uses web-based technology to quickly spread information and details to a wide range of users. It has changed the landscape of brand management and forces business firms to use a new interactive way to deal with their customers (Syrdal \& Briggs, 2018; van Asperen, de Rooij, \& Dijkmans, 2017).

In the customers' perspective, social media becomes a more trusted source, rival with the traditional mass media such as television, radio, and newspapers (Fritz, Schoenmueller, \& Bruhn, 2017).

In this new media, the speed and level of interaction are considered as the main advantage. Further, studies prove that customers have a positive attitude towards brands that are available in social media and who provide sufficient content for their users (Moretta Tartaglione, Cavacece, Russo, \& Granata, 2019; Romdonny \& Maulany, 2020).

Besides, social networks provide users with the flexibility to configure user settings, customize their profiles to appear in a certain way, edit their friends or followers, manage the information they see in news posts, and even give feedback on what they do or do not do or like.

\section{Findings}

The data, collected from qualitative the indepth interview, were analyzed using as a guidelines the suggestion of Susan McInnes et al. (2017). First, the authors developed a list of uses and gratifications derived from the researches and recommendations formulated by Plume and Slade (2018), Gironda and Korgaonkar (2016), and Narissra, La Cruz and Wrench (2017). Next, the authors independently read and reviewed the responses. As a final output, authors arranged the uses and gratifications comments into six groups (Figure 4 below) ${ }^{1}$ :

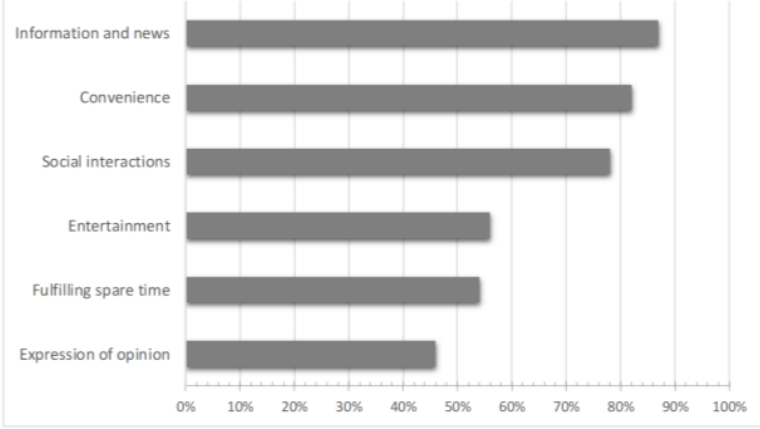

Figure 4.

Social media usage by type as reported by respondents

1) Social interaction - 78 percent of the respondents are using social media for social interaction. Respondents mentioned that social media is currently the only place where they can safely interact and socialize with others. Also, they have more contact with people via social media than face to face, especially with severe physical and social distancing measures in place, and that social media gives them the desired healthy social life, which, otherwise is limited due to the Covid-19 quarantine and the global "Stay at home" policies. The respondents indicated that they use social media to connect and stay in touch with their family and friends.

\footnotetext{
${ }^{1}$ Cumulative sum is exceeding $100 \%$, because the respondents were given an option for multiply answers as social media usage is not limited to one application only
} 
2) Information and news seeking and sharing - 87 percent of respondents are using social media to look for and share information and news (especially news and health information related to the new normal protocols, and social and physical distancing measures). The participants reported that they use social media:

- to find information about sales, discounts and promotion, or products;

- to find information about Covid-19 and related measures and policies;

- to find information on online events, webinars, discussions, and live-talks;

- to search for information about businesses and new business opportunities.

- to advertise their business and targeting potential customers.

- as a primary news source.

3) Filling spare time as the reason for using social media is reported by 54 percent. Respondents stated that they use social media when they have spare time or when they are bored and looking for something to do.

4) Entertainment - 56 percent of respondents reported that they used social media as a source of entertainment - playing games, listening to music, watching videos, and movies.

5) Expression of opinions as a way of social media use was mentioned by 46 percent of respondents. Respondents discoursed how they like to make comments such as liking postings and photos, commenting, and sharing comments on others' postings. Others discussed how they enjoyed the opportunity "to vent" on social media.

6) Convenience, as a type of social media use, was mentioned by 82 percent of respondents as it gives them convenience and accessibility anytime and anywhere with no time restraints.

The use of social media has drifted from being a primarily tool for entertainment and fulfilling a spare time toward an instrument and main source for news, information and educational apparatus.

In terms of media usage by platform, the top five most visited and used platforms, as reported by respondents, are YouTube, Facebook, Instagram, WhatsApp, and Facebook Messenger. The operating system (Android, iPhone, OS, Windows, and Linux) was considered irrelevant to the scope of this study, and their usage was not taken into account.

In the last decade, social media takes a significant part of human lives. Communication with family members, friends and colleagues is primarily performed via Internet. Nowadays, being restricted by the Covid-19 and the new normal protocols the continuous growth of the time spent on social media is not a surprise. In 2019 the daily time spent on social networking surpassed the 150 min mark, reaching an average of 153 min per day, or an increase of 1,4\% compared to 2018 . As social and physical distancing is still in effect, the projections for 2020 is that the upsurge will surpass $3 \%$.

In Indonesia, where this research was conducted, the first reported Covid-19 case is dated March $2^{\text {nd, }} 2020 . \quad$ Since then, Indonesians' patterns of using the Internet has changed dramatically. News and health-related searches in March 2020 saw a month-to-month increase of $8 \%$ and $53 \%$, respectively, compared to March 2019.

However, after the announcement and the following tightening of social and physical distancing and the suspension of classes, universities and schools across the country opted for online learning as a countermeasure to avoid the gap in the education process. The online learning's shift had resulted in a whopping $246 \%$ increase in education-related searches in March 2020 compared to March 2019 (Oh, 2020).

Findings, as presented above, clearly reveal a whole new role of social media in the era of new normal. From the theoretical perspective findings of this study propose the need of differentiation of type of use, so to create a comprehensive image of how social media gratifications has shifted as a result of the new normal.

Social media become a primary source of information, news (outpowering traditional media like TV, newspapers, and even dedicated news websites and information agencies) and also as the primary tool for promoting and expanding many businesses. New opportunities emerged in the hands of online creators, publishers, and marketers to commercialize this increase and alteration of news-related and overall media consumption habits of the citizens.

It is still uncertain what the consequences of this new normal will be and how long these 
new policies will last. However, the authors argue that the novel media behavior born from the new normal has replaced many assumptions, long taken for granted. A significant portion of respondents $(49 \%)$ claim that they will not return to their pre-new normal media behavior and will continue to rely heavily on social media for fulfilling their needs. At the same time, 37\% commented that they are still in the evaluation and may continue to rely on social media, especially if the new normal protocols stay in action for a prolonged period.

\section{CONCLUSIONS}

Utilisation of Internet nowadays has a numerous dimension, one of which is shaped under the term "social media". Exploitation of the information technology through the creation of web-based marketing media and the use of social media can be explored by the companies to promote their business, access information products, conduct business transactions, and conduct business communications globally, in order to expand their business networks, budget efficiently and economical. Consumption of social media is increasing with a rapid pace. Therefore, there is a burning need of understanding the ongoing changes in the way society is using the social media. This paper demonstrates the importance and usefulness of uses and gratifications theory

\section{REFERENCES}

Agustiningsih, G., Anindhita, W., \& Arisanty, M. (2017). Mapping of Indonesian Consumer Behavior on Social Media Netnography Study of Online Shopping Behavior on Social Media for Improving MSME in Indonesia. In The 3rd International Conference on Social and Political Science (ICoSaPS) (Vol. 2, p. 320). Jakarta: KnE Social Sciences. https://doi.org/10.18502/kss.v2i4.902

Arda, Ö. (2020). An Assessment of the New Media Documentary. OPUS Uluslararasl Toplum Araştırmaları Dergisi, 15(24), 11. https://doi.org/10.26466/opus.678458

Baumöl, U., Hollebeek, L., \& Jung, R. (2016). Dynamics of customer interaction on social media platforms. Electronic Markets, 26(3), 199-202. to researches, targeted at social media's way of use. The findings from the in-depth interviews provide a vibrant and comprehensive understanding of why people consume social media.

These findings can help media marketers and businesses to understand better the new role and new way social media is used. As a result, they will have at their disposal an incredibly powerful tool for more efficient and effective targeting, promoting, and communicating with their existing and potential customers. This research contributes to the existing social media-related literature in numerous ways. First, this paper contributes for academics and practitioners that uses and gratifications theory has specific relevance and should be given more importance and priority in researches in the field of social media and social media marketing. In addition, the paper's qualitative research methods provide a rich and comprehensive understanding of how and why consumers use social media, especially in a rapidly changing world when unforeseen circumstances are reshaping our established habits in all aspects of the human life. Last, but not the least, this research provides both academics and the business community with a comprehensive and up-to-date knowledge about the increasing influence of social media on people's lifestyle.

https://doi.org/10.1007/s12525-0160227-0

Fritz, K., Schoenmueller, V., \& Bruhn, M. (2017). Authenticity in branding exploring antecedents and consequences of brand authenticity. European Journal of Marketing, 51(2), 324-348. https://doi.org/10.1108/EJM-10-20140633

Gironda, J. T., \& Korgaonkar, P. K. (2016). Personalized Advertising, Invasiveness, and Consumers' Attitudes: A Structured Abstract. In K. Kim (Ed.), Celebrating America's Pastimes: Baseball, Hot Dogs, Apple Pie and Marketing?. Developments in Marketing Science: Proceedings of the Academy of Marketing Science (pp. 165169). Springer, Cham. https://doi.org/10.1007/978-3-319-266473_30 
Hollenbaugh, E. E., Ferris, A. L., \& Casey, D. J. (2020). How Do Social Media Impact Interpersonal Communication Competence?: A Uses and Gratifications Approach. In M. Desjarlais (Ed.), The Psychology and Dynamics Behind Social Media Interactions (1st ed., pp. 137163). IGI Global. https://doi.org/10.4018/978-1-5225-94123.ch006

Innova, E. I. (2016). Motif dan Kepuasan Pengguna Instagram di Komunitas Instameet Indonesia. Jurnal EKomunikasi, 4(2).

Kaye, B. K., \& Johnson, T. J. (2017). Strengthening the Core: Examining Interactivity, Credibility, and Reliance as Measures of Social Media Use. Electronic News, 11(3), 145-165. https://doi.org/10.1177/19312431166722 62

Laura, F., \& Corwin, S. (2020). Restarting with Covid-19: Seven Key Action Items. Catalyst Non-Issue Content, 1(3). https://doi.org/10.1056/CAT.20.0207

Lev-On, A. (2017). Uses and Gratifications: Evidence for Various Media. In P. Rössler, C. A. Hoffner, \& L. Zoonen (Eds.), The International Encyclopedia of Media Effects (pp. 1-9). Wiley. https://doi.org/10.1002/9781118783764. wbieme0046

McInnes, S., Peters, K., Bonney, A. D., Halcomb, E. J., Mcinnes, S., Peters, K., \& Bonney, A. (2017). An exemplar of naturalistic inquiry in general practice research. Nurse Researcher (Vol. 24). Retrieved from https://ro.uow.edu.au/smhpapers/4302

Meservy, T. O., Fadel, K., Nelson, B., \& Matthews, M. (2019). Production vs. Consumption on Social Media: A Uses and Gratifications Perspective. In Twenty-fifth Americas Conference on Information Systems 2019, Proceedings. Cancun: Association for Information Systems. Retrieved from https://aisel.aisnet.org/amcis2019/virtual_ communities/virtual_communities/9

Moretta Tartaglione, A., Cavacece, Y., Russo, G., \& Granata, G. (2019). A Systematic Mapping Study on Customer Loyalty and Brand Management. Administrative
Sciences, $\quad 9(1), \quad 8$. https://doi.org/10.3390/admsci9010008

Oh, S. (2020, May 13). How COVID-19 has continued to impact Digital Media Consumption in APAC. Retrieved May 21, 2020, from https://www.comscore.com/Insights/Blog /How-COVID-19-has-continued-toimpact-Digital-Media-Consumption-inAPAC-March-2020

Plume, C. J., \& Slade, E. L. (2018). Sharing of Sponsored Advertisements on Social Media: A Uses and Gratifications Perspective. Information Systems Frontiers, 20(3), 471-483. https://doi.org/10.1007/s10796-0179821-8

Punyanunt-Carter, N. M., De La Cruz, J. J., \& Wrench, J. S. (2017). Investigating the relationships among college students' satisfaction, addiction, needs, communication apprehension, motives, and uses \& gratifications with Snapchat. Computers in Human Behavior, 75, 870875.

https://doi.org/10.1016/j.chb.2017.06.034

Rokito, S., Choi, Y. H., Taylor, S. H., \& Bazarova, N. N. (2019). Over-gratified, under-gratified, or just right? Applying the gratification discrepancy approach to investigate recurrent Facebook use. Computers in Human Behavior, 93, 7683. https://doi.org/10.1016/j.chb.2018.11.041

Romdonny, J., \& Maulany, S. (2020). Contribution of Social Media in Increasing Marketing of Creative Economy Product. In Proceedings of the 1st International Conference on Accounting, Management and Entrepreneurship (ICAMER 2019) (pp. 87-90). Atlantis Press. https://doi.org/10.2991/aebmr.k.200305.0 22

Schlagwein, D., \& Hu, M. (2018). How and why Organisations use Social Media: Five Use Types and their Relation to Absorptive Capacity. Journal of Information Technology, 33(4), 361-362. https://doi.org/10.1057/s41265-0180057-y

Sohrabi, C., Alsafi, Z., O’Neill, N., Khan, M., Kerwan, A., Al-Jabir, A., ... Agha, R. 
(2020, April 1). World Health Organization declares global emergency: A review of the 2019 novel coronavirus (COVID-19). International Journal of Surgery. Elsevier Ltd. https://doi.org/10.1016/j.jisu.2020.02.034

Syrdal, H. A., \& Briggs, E. (2018). Engagement With Social Media Content: A Qualitative Exploration. Journal of Marketing Theory and Practice, 26(1-2), 4-22.

https://doi.org/10.1080/10696679.2017.1 389243

Ting, D. S. W., Carin, L., Dzau, V., \& Wong, T. Y. (2020, April 1). Digital technology and COVID-19. Nature Medicine. Nature Research.

https://doi.org/10.1038/s41591-0200824-5

van Asperen, M., de Rooij, P., \& Dijkmans, C. (2017). Engagement-Based Loyalty: The Effects of Social Media Engagement on Customer Loyalty in the Travel Industry. International Journal of Hospitality and Tourism Administration, 1-17. https://doi.org/10.1080/15256480.2017.1 305313

Wang, P., Li, H., \& Suomi, R. (2016). Value Co-Creation in Business via Social Media: A Technology Affordance Approach. In PACIS 2016 Proceedings (p. 355). Retrieved from https://aisel.aisnet.org/pacis2016/355

\section{AUTHORS BIOGRAPHY}

\section{Rety Palupi,}

Rety as a Digital Public Relations Specialist. She completed her undergraduate education at BSI University in Bandung. And finished studies at the Masters in Communication Studies at Budi Luhur University, Jakarta. Currently she is one of the lecturers in the Public Relations Study Program, Faculty of Communication and Language, Bina Sarana Informatics University.

\section{Mincho Slavov,}

Mincho as a foreign Post-Graduate student at Airlangga University, Human Resources Development, Post-Doctoral. Has been finished studies at Universitas Gadjah Mada (Yogyakarta), Tourism Studies, Postgraduate School. 